\title{
What a family really is? The question about the legal definition of a family. The UK case study example
}

\author{
According to the Black's law dictionary, ${ }^{1}$ a family is a collective body of persons \\ who live in one house and under one head or management. This particular
}

* Magdalena Butrymowicz works as an asistant professor at the Pontifical University of John Paul II in Krakow and was a visiting scholar at the Arizona University. She is also a practicing solicitor in the area of the family and human rights law. She participated and presented many papers at various international conferences.

1 "A collective body of persons who live in one house and under one head or management. Tahoe v. Jarboe, Dodge v. Boston \& T. R. Corp., Tyson v. Reynolds. A family comprises a father, mother, and children. In a wider sense, it may include domestic servants; all who live in one house under one head. In a still broader sense, a group of blood-relatives; all the relations who descend from a common ancestor, or who spring from a common root. See Civil Code La. art. 3522, No. 16; 9 Ves. 323. A husband and wife living together may constitute a "family," within the meaning of that word as used in homestead law. Miller v. Finegan: "Family," in its origin, meant "servants;" but, in its more modern and comprehensive meaning, it signifies a collective body of persons living together in one house, or within the curtilage, in legal phrase. Wilson v. Cochran: "Family" may mean children, wife and children, blood-relatives, or the members of the domestic circle, according to the connection in which the word is used. Spencer v. Spencer, 11 Paige (N. Y.), 159. "Family," in popular acceptation, includes parents, children, and servants." What is FAMILY?, in: The law dictionary. Featuring Black's law dictionary free online legal dictionary $2^{\text {nd }}$ edition, http://thelawdictionary.org/family/ (05.04.2016). 
definition was provided for different court rulings. ${ }^{2}$ In the same dictionary, under the question what a family is, it is described as a whole household, including servants and all blood-relatives. In fact, it is difficult to describe what a family is? Who constitutes it? This is because the definition of a family is on the move, is linked to society and changing in similar ways as society is. The circle of family members has broadened over the years, for example with stepchildren or disabled children. ${ }^{3}$

\section{Family in scholars' opinion}

The difficulty of defining a family comes generally from differences in its perception in cultures and societies. Hence, alternative look on a family in different cultures through blood ties rather than legal establishments, or through closeness that a particular person has with other human beings or even animals. ${ }^{4}$

In general, in accordance with the legal definition, a "family" is constituted by blood ties and by law. It can be said that there are two types of a family: a blood-related and a law-related. This solution can be found in in articles $61^{7}$ and $61^{8}$ of the Polish Family and Guardianship Code which clearly separates a blood family from a legal family. ${ }^{5}$

This traditional concept of a family is highly criticized by a British researcher Jonathan Herring who wrote that a contrario this type of a family would rise controversy and is an archetype. However, next he stresses that from the legal perspective, a family is based on marital and blood relations. ${ }^{6}$

2 Tahoe v. Jarboe, 100 Mo. App. 459, 79 S. W. 1162.

3 R. Probert, Family law in England and Wales, Bedfordshire 2011, p. 25.

4 G. Lewis, Forming nation. Framing welfare, New York 1998, p. 232.

5 Art. $61^{7}$. [Consanguinity] $\$ 1$. "Relatives in direct line are persons, out of whom one descends from the other. Collateral relatives are persons who descend from the common ancestor and are not relatives in direct line. $\$ 2$. The degree of consanguinity is determined according to the number of births through which consanguinity occurred."

Art. $61^{8}$. [Affinity] $\$ 1$. "Affinity between one spouse and the other spouse's relatives results from the spouses' marriage. It continues despite the cessation of the marriage. $\$ 2$. The degree and the line of affinity are determined according to the degree and the kinship line." The Family and Guardianship Code of 25 February 1964 ("Journal of Laws" of 2015, item 2082 as amended).

6 J. Herring, Family law: a very short introduction, New York 2014, pp. 3-4. 
Actually, in his other book written together with Rebecca Probert, Jonathan Herring argues that there are relatively few circumstances in law when there is a need to define a family. ${ }^{7}$

Alison Diduck, another British scholar, defines a family as "an expression of intimate or private living based upon care and interdependence." ${ }^{8}$ Other researchers, similarly to Probert, point out that the definition of a family is changing due to changes in society. Anthony Gidens indicates that the sexual revolution in the sixties loosened family ties and the understanding of a family has become open-ended. He also correctly observes that now partners in marriage stay together as long as they continue to get something from it. There are also other voices that decelerated these changes in a family as a risk for society and treated such an extended concept of a family as a dysfunction. So, for them, a family is a community of relatives (by blood or legal bond), and all others who we consider as close to us, like friends or neighbors. According to Ruth Deech, the law should not support such a community or treat it as a family. She supports a traditional marriage and traditional obligations, which come from such a marriage, and specifies the role of a nuclear family in developing health and stable society. ${ }^{9}$ Anthony Giddens tries to reconcile these contradictory voices. He claims that a family, no matter how constructed, should have one goal: the well-being of children. On the one hand, the equality and freedom should be at the core of the value system, and it is necessary to redefine the rights and obligations of this social unit that a family is. On the other, this will lead to a new definition of a family. ${ }^{10}$

The modern legal definition of a family puts an emphasis on relationships that deserve legal support. Scholars argue that in this particular relation, sex orientation, existence of children or cohabitation are not important. Therefore, a family is only such a type of a relation in which one person depends on the other. Jonathan Herring supports this particular definition. He argues that

7 J. Herring, R. Probert, S. Glimore, Great debates in family law, London 2015, p. 4.

8 A. Diduck, What is family law for?, "Current Legal Problems" 64 (2011) issue 1, pp. 287314, http://clp.oxfordjournals.org/content/64/1/287.abstract (10.12.2016).

9 R. Deech, Family law and genetics, in: Law and human genetics: regulating a revolution, ed. R. Brownsword, Oxford 1999, p. 105.

10 A. Carling, S. Duncan, R. Edwards, Analysing families: morality and rationality in policy and practice, London 2002, pp. 127-128. 
we have to use the term "family" to each social unit in which there is care for each other. Such a relation is subject to unfavorable economic circumstances, and this is the main reason why it should be protected. ${ }^{11}$

To summarize these doctrinal voices, it can be said that the modern scholars' definition of a family follows Jonathan Herring's idea that a family is such a social unit that is bonded together by the dependency. Most of them also agree that such a phenomenon as a family is undefined and there is no legal need to create its definition.

\section{Legal definition of a family derived from legal acts}

A non-legal definition of a family exists in the United Kingdom. ${ }^{12}$ As it was said above, this statement was however criticized by Jonathan Herring who rightly explained that law needs a precise definition of a family, because without it, there is great danger of not seeking to promote family life or not to talk about family law. In case of a lack of the definition, family law will be unable to determine which group to cover. ${ }^{13}$ In such a case, family law will only apply to one group and neglect the other which should be also covered by it. There is no perfect legal definition of "a family," but in the British legal system, almost each act which covers the social unit that we call "a family" defines this term for the proposes of itself.

In immigration law, for example, in the Detention Service Order 1/2014, ${ }^{14}$ an instruction in picture 2, a family is defined really broadly. In general, it should be considered as any type of a married or unmarried couple, with or without children, whether homosexual or heterosexual. Likewise, a family should be considered as any social unit of adults, like fathers, mothers, grandparents, aunts and uncles, cohabitating with children..$^{15}$ There is also

11 J. Herring, R. Probert, S. Glimore, Great debates in family law, London 2015, p. 10.

12 P. R. Ghandhi, E. Macnamee, The family in UK law and the International Covenant on Civil and Political Rights 1966, "International Journal of Law, Policy and the Family" 1991 No. 5 (2), pp. 104-131, http://lawfam.oxfordjournals.org/content/5/2/104.abstract (10.12.2016).

13 J. Herring, R. Probert, S. Glimore, Great debates in family law, London 2015, p. 6.

14 Home Office, Detention service order 1/2014 (replaced DSO 11/2011).

15 "Two parents, married or unmarried, and their dependent children, including dependent children who may be 18 or over. A single parent or other adult carer/guardian with 
an open clause which allows immigration officers to interpreter a given situation according to the facts that they encounter during their work. ${ }^{16}$

According to the Rent Act 1977 (later modified by the Housing Act 1988 and others), the original family of the tenant is a spouse or any family member living with the tenant at the time of his death. ${ }^{17}$ The definition broadens the tenant's family to any relative or any person who can be called spouse or whom the tenant treats like a spouse, and gives them the status of the tenant's original family. A family is also mentioned in a few other places in this act and in the Housing Act, each time referring to persons with whom the tenant

dependent children, including dependent children who may be 18 or over. An extended family unit that may include, for example, one or two parents, grandparent(s), aunt(s), uncle(s) or any combination of extended family members with dependent children. A couple, married or unmarried, without dependent children. A same sex couple, with or without dependent children. An older sibling (18 or over) with dependent younger siblings under 18 or 18 or over but vulnerable by reason of mental or physical disability." Home Office, Detention service order 1/2014 (replaced DSO 11/2011).

16 "Where other groupings present themselves as a family unit, it will be necessary to consider carefully the truthfulness of the relationships and whether all members of the family unit should be accommodated together as a family." Home Office, Detention service order 1/2014 (replaced DSO 11/2011).

17 "The surviving spouse (if any) of the original tenant, if residing in the dwelling-house immediately before the death of the original tenant, shall after the death be the statutory tenant if and so long as he or she occupies the dwelling-house as his or her residence. (2) For the purposes of this paragraph, a person who was living with the original tenant as his or her wife or husband shall be treated as the spouse of the original tenant.

(3) If, immediately after the death of the original tenant, there is, by virtue of subparagraph (2) above, more than one person who fulfils the conditions in sub-paragraph (1) above, such one of them as may be decided by agreement or, in default of agreement, by the county court shall be treated as the surviving spouse for the purposes of this paragraph. 1) Where a person who - (a) was a member of the original tenant's family immediately before that tenant's death, and (b) was a member of the first successor's family immediately before the first successor's death, was residing in the dwelling-house with the first successor at the time of, and for the period of 2 years immediately before, the first successor's death, that person or, if there is more than one such person, such one of them as may be decided by agreement or, in default of agreement, by the county court shall be entitled to an assured tenancy of the dwelling-house by succession. (2) If the first successor died within the period of 18 months beginning on the operative date, then, for the purposes of this paragraph, a person who was residing in the dwelling-house with the first successor at the time of his death and for the period which began 6 months before the operative date and ended at the time of his death shall be taken to have been residing with the first successor for the period of 2 years immediately before his death." The Rent Act 1977 c. 42. 
has a good close relation and who cohabit with the tenant or are the subject of some legal arrangements concerning the tenant's house. ${ }^{18}$

Another legal act in which a family is described is the Human Rights Act. ${ }^{19}$ The British human rights law is based on the articles of the European Convention of Human Rights. ${ }^{20}$ The Act "gives further effect" to the rights and freedoms guaranteed under the European Convention. In article 8 of the Act we can read that everybody has the right of being respected for their established family life. This includes close family ties, although there is no pre-determined model of a family or family life. However, according to the judgments of the European Court of Justice, a family can be understood as any stable relationship, be it married, engaged, or de facto between parents and children, siblings, grandparents and grandchildren or other persons. Solicitors often use this particular rule of law to protect the integrity of the family, when measures are taken by the state to separate family members (by removing children into care, or deporting one member of a family group). In such a situation, in court or in front of the authority, they prove that their client has the strong bond with other members of their household or with other persons, and that this bond can be defined as family ties. ${ }^{21}$

Another act which should be mentioned here is the Care Act. ${ }^{22}$ There is no definition of a family in the act itself, but in the explanatory note officially issued by the government for practitioners working in adult social care. It is said that by a family they should understand parents, children, stepchildren, grandparents, children of partners or an extended family. ${ }^{23}$

Of course, there are also other legal documents in which the government tried to explain what a family means for the legal purposes. However it can be commonly noticed that in each case, the definition of a family is created

18 The Housing Act 1988 c. 50.

19 The Human Rights Act 1998 c. 42.

20 The Convention for the Protection of Human Rights and Fundamental Freedoms, Rome, 4 November 1950.

21 "Everyone has the right to respect for his private and family life, his home and his correspondence. There shall be no interference by a public authority with the exercise of this right except such as is in accordance with the law and is necessary in a democratic society in the interests of national security, public safety or the economic well-being of the country, for the prevention of disorder or crime, for the protection of health or morals, or for the protection of the rights and freedoms of others." Human Rights Act 1998 c. 42.

22 The Care Act 2014 c. 23.

23 Department of Health, The Care Act and whole-family approaches, London 2015, pp. 3-5. 
in the most descriptive way possible, and always there is an open window for its further broadening. In each case, the legislator underlines the importance of relations which exist between people who claim that they are a family. If such a bond is strong enough and the element of dependency exists, British lawmaker orders to treat such a group as a family.

\section{Definition of a family in court judgments}

In many judgments, the British Supreme Court and the Appeal Court proclaim how the word "family" should be interpreted. In Helby v. Rafferty, ${ }^{24}$ the court at first decided to refuse to recognize a man who had lived with a woman tenant for five years before her death as part of the same family. In the court's opinion, the fact that they had deliberately opted to retain their formal independence, means that they had not been recognized as being married. However, in the same court's judgment, it was decided that a woman who has had a permanent relationship with a man for a certain period of time, but has not been married to him, may, nonetheless, have acquired the status of a member of that man's family. ${ }^{25}$

Another case worth mentioning is Watson v. Lucas, ${ }^{26}$ in which the judges were trying to answer the question if a woman who lived with a man, although he remained married to his wife, would be a member of his family? The court answer was positive. The judges decided that because it was the man's last relation before his death, the woman should be considered as a member of his family. ${ }^{27}$ A similar judgment was passed in Dyson Holdings Ltd. v. Fox. ${ }^{28}$ In this case, Lord Alfred Denning declared that the term "family" is not fixed once and for all. Another case, based on similar facts was Hawes v. Evenden, ${ }^{29}$

24 Helby v. Rafferty [1979] 1 W.L.R. 13, http://swarb.co.uk/helby-v-rafferty-ca-1979/ (09.04.2016).

25 Helby v. Rafferty...

26 Watson v. Lucas [1980] 1 W.L.R. 1493, http://swarb.co.uk/watson-v-lucas-ca-1980/ (09.04.2016).

27 Watson v. Lucas...

28 Dyson Holdings Ltd. v. Fox, CA 1976, http://swarb.co.uk/dyson-holdings-ltd-v-foxCA-1976/ (10.03.2016).

29 Hawes v. Evenden [1953] 1 W.L.R. 1169, http://swarb.co.uk/hawes-v-evenden-ca-1953/ (24.03.2016). 
where an unmarried woman who had lived with the deceased man for 12 years and had had two children with him, claimed to be a member of his family. The court held that there was evidence that she, the man and the children had lived together as a family and therefore she was considered a member thereof. ${ }^{30}$

A further case was Chios Property Investment Ltd. v. Lopez. ${ }^{31}$ Here the court stressed that a "sufficient state of permanence and stability" has been reached in the relationship so as to constitute a family. In Jones $v$. Whitehill, ${ }^{32}$ the court decided not to follow the blood or law definition of a family, quoting that also "step" relatives are family members. ${ }^{33}$

In Michalak v. London Borough of Wandsworth, ${ }^{34}$ the Appeal Court decided that lawmaker can narrow the definition of a family according to his necessity and there is no infringement of the right to family life. The Court also established a four-fold test for discrimination under the Convention of Human Rights: "(i) do the facts fall within the scope of one or more of the substantive Convention provisions? (ii) if so, was there different treatment in respect of that right between the complainant on the one hand and other persons putting forward for comparison ("the chosen comparators") on the other? (iii) were the chosen comparators in an analogous situation to the complainant's situation? (iv) if so, did the difference have an objective and reasonable justification." 35

The most important court judgment in British legal history is: Fitzpatrick v. Sterling Housing Association Ltd., granted on 28 October $1999 .{ }^{36}$ In this case, which arose around the dispute over statutory tenancy rights, judges who were resolving the dispute had to answer the question what the word "family" means in the British legal system? Finally the decision was reached

30 Hawes v. Evenden...

31 Chios Property Investment Ltd. v. Lopez (1987) 20 H.L.R. 120, http://swarb.co.uk/chiosproperty-investment-ltd-v-lopez-1987/ (07.04.2016).

32 Jones $v$. Whitehill [1950] 2 K.B. 204, http://swarb.co.uk/jones-v-whitehill-ca-1950/ (25.04.2016).

33 Jones $v$. Whitehill...

34 Michalak v. London Borough of Wandsworth, CA 6 Mar 2002, http://swarb.co.uk/ michalak-v-london-borough-of-wandsworth-ca-6-mar-2002-3/ (01.02.2016).

35 Michalak v. London Borough of Wandsworth...

36 Fitzpatrick (A. P.) v. Sterling Housing Association Ltd., HL 28 Oct 1999, http://www. publications.parliament.uk/pa/ld199899/ldjudgmt/jd991028/fitz01.htm (09.04.2016). 
and 'the meaning of 'member of a family' could include a same sex partner who had been involved in an established monogamous relationship. Such a person could not be a "spouse" within the meaning of the Act, but the family provision was more widely framed and allowed the court to take account of changes in society. Thus a same sex partner could take a succession of a property from that partner on death on the basis of his being a member of the family. "The hallmarks of the relationship were essentially that there should be a degree of mutual inter-dependence, of the sharing of lives, of caring and love, of commitment and support. In respect of legal relationships, these are presumed, though evidently not always present, as the family law and criminal courts know only too well. In de facto relationships these are capable, if proved, of creating membership of the tenant's family." ${ }^{37}$

It is worth noting that British courts play important role in defining the meaning of a family for the legal purposes. The courts are responsible for changing the legal attitude towards the understanding who can be a member of the family. They broaden the definition to the possible limits and push British legislator to change the law in such a way so that it will not discriminate other groups which previously were not treated as family members.

\section{Summary}

Taking all into account, it can be stated that the word "family" in the past meant a legal relationship created by blood, legal ceremony or legal adoption. Through the society changes, the definition has also changed and the meaning of a family has broadened. The milestone was the Supreme Court's judgment in the Fitzpatrick case were the judges decided that a family must be understood also as relationships other than those based on consanguinity or affinity. It was clearly marked that a family must be perceived as having a special bond which connects particular people, and this bond can be either law- or blood-related. This was also Jonathan Herring's argumentation, and the British legislature and courts followed his opinion about the extended understanding of a family.

37 Fitzpatrick v. Sterling Housing Association Ltd... 


\section{Bibliography}

\section{Dictionaries:}

What is FAMILY?, in: The law dictionary. Featuring Black's law dictionary free online legal dictionary $2^{\text {nd }}$ edition http://thelawdictionary.org/family/ (05.04.2016).

\section{Court cases:}

Chios Property Investment Ltd. v. Lopez (1987) 20 H.L.R. 120, http://swarb.co.uk/ chios-property-investment-ltd-v-lopez-1987/(07.04. 2016).

Dyson Holdings Ltd. v. Fox; CA 1976, http://swarb.co.uk/dyson-holdings-ltd-vfox-CA-1976/ (10.03.2016).

Fitzpatrick (A. P.) v. Sterling Housing Association Ltd., HL 28 Oct 1999, http:// www.publications.parliament.uk/pa/ld199899/ldjudgmt/jd991028/fitz01.htm (09.04.2016).

Hawes v. Evenden [1953] 1 W.L.R. 1169, http://swarb.co.uk/hawes-v-evendenca-1953/ (24.03.2016).

Helby v. Rafferty [1979] 1 W.L.R. 13, http://swarb.co.uk/helby-v-rafferty-ca-1979/ (09.04.2016).

Jones $v$. Whitehill [1950] 2 K.B. 204, http://swarb.co.uk/jones-v-whitehill-ca-1950/ (25.04.2016).

Michalak v. London Borough of Wandsworth, CA 6 Mar 2002, http://swarb.co.uk/ michalak-v-london-borough-of-wandsworth-ca-6-mar-2002-3/ (01.02.2016).

Tahoe v. Jarboe, 100 Mo. App. 459, 79 S. W. 1162.

Watson v. Lucas [1980] 1 W.L.R. 1493, http://swarb.co.uk/watson-v-lucas-ca-1980/ (09.04.2016).

Acts:

The Convention for the Protection of Human Rights and Fundamental Freedoms, Rome, 4 November 1950.

The Care Act 2014, c. 23.

The Housing Act 1988, c. 50.

The Human Rights Act 1998, c. 42. 
Ustawa z dnia 25 lutego 1964 r. Kodeks rodzinny i opiekuńczy, Dz. U. z 2015 r., poz. 2082 z późn. zm. (English translation: The Family and Guardianship Code of 25 February 1964 ["Journal of Laws" No. 9, item 59 as amended], bilingual edition, transl. N. Faulkner, Warszawa 2010).

The Rent Act 1977, c. 42.

\section{Literature:}

Carling A., Duncan S., Edwards R., Analysing families: morality and rationality in policy and practice, London 2002.

Deech R., Family law and genetics, in: Law and human genetics: regulating a revolution, ed. R. Brownsword, Oxford 1999.

Department of Health, The Care Act and whole-family approaches, London 2015, pp. 3-5.

Diduck A., What is family law for?, "Current Legal Problems" 64 (2011) issue 1, pp. 287-314, http://clp.oxfordjournals.org/content/64/1/287.abstract (10.12.2016).

Ghandhi P. R., McNamee E., The family in UK law and the International Covenant on Civil and Political Rights 1966, "International Journal of Law, Policy and the Family” 1991 No. 5 (2), pp. 104-131, http://lawfam.oxfordjournals.org/ content/5/2/104.abstract (10.12.2016).

Herring J., Family law: a very short introduction, New York 2014.

Herring J., Probert R., Gilmore S., Great debates in family law, London 2015.

Lewis G., Forming nation. Framing welfare, New York 1998.

Probert R., Family law in England and Wales, Bedfordshire 2011.

Home Office, Detention service order 1/2014 (replaced DSO 11/2011). 